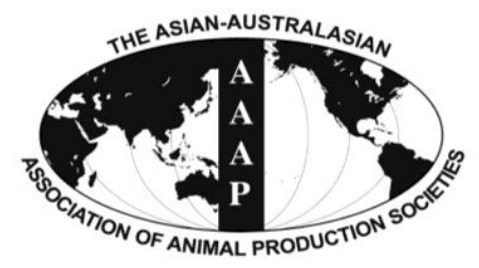

Asian-Aust. J. Anim. Sci.

Vol. 25, No. 4 : 524 - 530

April 2012

www.ajas.info

http://dx.doi.org/10.5713/ajas.2011.11375

\title{
The Long Term Effects of Fairly Low-level of Supplemental Fat on the Productive Performance of Commercial Layers
}

\author{
Mehmet Bozkurt*, Kamil Küçükyılmaz, Metin Çabuk ${ }^{1}$ and Abdullah Uğur Çatlı \\ Erbeyli Poultry Research Institute, İncirliova/Aydın, Turkey
}

\begin{abstract}
Laying hens were fed commercial diets added with supplemented fat (SFAT) at $0.6,1.2$, and $1.8 \%$ in order to study the long term dietary effects - on - their productive performance from 22 to 75 wk of age. Five hundred and seventy six Single Comb White Leghorn hens were assigned to one of the four dietary treatments. The experimental phase consisted of three periods of 18 wk each. The final body weight and gain of hens fed on diets with SFAT at $1.2 \%$ and $1.8 \%$ were lower $(\mathrm{p}<0.05)$ than those hens given no SFAT. The SFAT at the $1.2 \%$ and $1.8 \%$ levels improved egg production rate, egg weight and mass, as well as FCR. Mortality and feed consumption were not affected by dietary SFAT. Administration of a diet with SFAT significantly decreased the cracked-broken egg ratio ( $<<0.01$ ). The beneficial effects of SFAT on egg production performance were particularly more pronounced at intermediate and later ages. Hence, SFAT by period interactions were significant for all traits studied except feed intake. Hens fed SFAT deposited significantly higher abdominal fat than those on the no-SFAT diet. As a result, SFAT at $1.2 \%$ and $1.8 \%$ inclusion levels provided benefits in terms of efficient table egg production. (Key Words : Supplemental Fat, Laying Hen, Performance, Liver and Abdominal Fat Weight)
\end{abstract}

\section{INTRODUCTION}

Dietary addition of fats and oils has been the most practical method of increasing energy density of poultry diets. Supplemented fat (SFAT) as animal origin (i.e. fish oil, tallow, lard, poultry fat) are common feed ingredients for supplemental fats in layer hens and proved beneficial for productive performance, including egg production rate, feed conversion efficiency and egg weight (Scragg et al., 1987; Sell et al., 1987; Grobas et al., 1999).

Beneficial effect of linoleic acid on egg weight in laying hen nutrition has been long known. There is a good bulk of evidence reporting that increased dietary linoleic acid content improves egg weight in leghorn hens (Shutze and Lesson, 1963; Whitehead, 1981; March and MacMillan, 1990). Previous research showed also that SFAT exerts a favorable effect on egg weight beyond that attributable to an increase in linoleic acid concentration (Sell et al., 1987; Keshavarz, 1995; Grobas et al., 1999).

In order to investigate the metabolic effects of SFAT in

\footnotetext{
* Corresponding Author : Mehmet Bozkurt. Tel : +90-2565811123, Fax : +90-256-5811123, E-mail : mehmetbozkurt9@ hotmail.com

1 Department of Poultry Science, Vocational School of Celal Bayar University, Akhisar, Manisa, Turkey.

Submitted Oct. 18, 2011; Accepted Dec. 6, 2011; Revised Dec. 15, 2011
}

diets for laying hens, fats including fish oil (FO) were included into diets at extremely high levels up to $6 \%$ in many cases. For this purpose, experimental laying hen diets were intentionally formulated on wheat, exceeding $600 \mathrm{~kg}$, so as to maximize the dietary fat level (Grobas et al., 1999; Baucells et al., 2000). This is because wheat contains fewer metabolic energy by $10 \%$ as compared to that of corn, hence, more SFAT was included into wheat based laying hen diets to meet the dietary energy level as recommended by the breeder. However, in standard practical layer hen diets based on corn and soybean meal, it is not necessary to incorporate such extremely high fat levels in order to fulfill the energy requirements, since the energy was mainly provided by the corn (da Silva et al., 2005). Nevertheless, to date a limited amount of scientific experiments have been conducted to evaluate the relationship between layer hen age and the fairly low-level of dietary fat supplementation with regard to performance when hens are fed corn-soybean based diets. Therefore, this study evaluated the influence of fish oil (FO) as an SFAT at three levels of inclusion on the productive performance of laying hens over whole laying cycle.

\section{MATERIALS AND METHODS}

Five hundred and seventy six 19-week-old Single Comb 
White Leghorn pullets (Nick Chick) were obtained for this study. Hens were caged three to a pen that was $45 \times 40 \times 50$ $\mathrm{cm}$ in size, and assigned to one of four dietary treatments. Each treatment consisted of six replications of eight cages. Hens were placed in a curtain-sided open house with natural ventilation in which the temperature ranged from $10^{\circ} \mathrm{C}$ to $32^{\circ} \mathrm{C}$ depending on natural seasonal variations. A photoperiod of $16 \mathrm{~h} / \mathrm{d}$ was established. Experimental periods I, II, and III corresponded to ages 22 to 39 wks, 40 to $57 \mathrm{wks}$, and 58 to $75 \mathrm{wks}$, respectively. Hence, a whole production cycle consisted of $3 \times 18$-wk periods.

A corn-soybean based diet with no added SFAT was used as control, and basal diets supplemented with FO (anchovy) at $0.6 \%, 1.2 \%$, and $1.8 \%$ were fed to hens throughout the experimental period. The diets were gradually introduced to hens between 19 to 22 wks of age. Mash diets and water were provided for ad libitum. The SFATs were stored in plastic barrels in $200 \mathrm{~kg}$ amounts throughout the experimental period. A $0.5 \mathrm{~g} / \mathrm{kg}$ antioxidant combination was added to the SFAT at the commencement of the study. The antioxidant combination provided the following: BHA (7.5 mg/g fat), ethoxyquine (40 mg/g fat), BHT (90 mg/g fat), and citric acid (30 mg/g fat).

All birds were weighed individually at 22 and $75 \mathrm{wks}$ of age. Egg production rate (\% hen-d) and the cracked-tobroken egg ratio (\%) were recorded on a daily basis determining on a replicate basis throughout the experiment. Seventy-two eggs (six eggs per replicate) that were not deformed, excessively small or large, or double-yolked for each treatment were randomly selected and collected on two consecutive days each week and weighed individually. Mortality was determined as percentage mortality for the overall duration of the trial. Egg mass output was calculated by multiplying the percentage of hen-day egg production by the average egg weight in grams. Feed intake (g/bird/d) was measured for each week and calculated as a mean for each replicate. The feed conversion ratio (FCR) was described as $\mathrm{kg}$ of feed consumption per $\mathrm{kg}$ egg mass. The magnitude of production variables, such as feed intake and egg production, were adjusted for hen mortalities.

At the end of the study, twelve hens from each treatment were randomly selected based on the average body weight within the treatment. Sampled hens were electrically stunned, and slaughtered. The liver and abdominal fat pad were carefully excised and weighed.

The fatty acid profiles for the SFAT and the experimental diets (Table 1) were determined according to the method from the Association of Analytical Chemists

Table 1. Fatty acid composition of the fish oil (SFAT) and experimental diets ( $\%$ of total fatty acids) ${ }^{1}$

\begin{tabular}{|c|c|c|c|c|c|}
\hline \multirow{2}{*}{ Fatty acid } & \multirow{2}{*}{ SFAT $^{2}$} & \multicolumn{4}{|c|}{ Experimetal diets with SFAT (\%) } \\
\hline & & 0.0 & 0.6 & 1.2 & 1.8 \\
\hline $\mathrm{C}_{12.0}$ Lauric & 3.04 & - & - & - & - \\
\hline $\mathrm{C}_{14: 0}$ Myristic & 7.72 & 1.31 & 2.08 & 2.21 & 2.46 \\
\hline $\mathrm{C}_{16: 0}$ Palmitic & 18.62 & 17.14 & 17.44 & 17.89 & 18.67 \\
\hline $\mathrm{C}_{16: 1}$ Palmitoleic & 9.44 & 1.47 & 2.37 & 2.72 & 2.96 \\
\hline $\mathrm{C}_{18: 0}$ Stearic & 7.83 & 5.85 & 6.58 & 6.81 & 6.53 \\
\hline $\mathrm{C}_{18: 1 \mathrm{n}-9}$ Oleic & 23.09 & 24.81 & 28.43 & 28.78 & 31.01 \\
\hline $\mathrm{C}_{18: 2 \mathrm{n}-6}$ Linoleic & 4.86 & 29.94 & 31.53 & 33.44 & 34.47 \\
\hline $\mathrm{C}_{18: 3 \mathrm{n}-3}$ Linolenic & 2.65 & 1.55 & 1.66 & 1.78 & 1.98 \\
\hline $\mathrm{C}_{20: \ln -9}$ Eicosenoic & - & 0.96 & 0.90 & 0.91 & 0.82 \\
\hline $\mathrm{C}_{18: 4 \mathrm{n}-3}$ Stearidonic & 1.26 & - & - & - & - \\
\hline $\mathrm{C}_{20: 4 \mathrm{n}-6}$ Arachidonic & 1.68 & 0.49 & 0.56 & 0.61 & 0.63 \\
\hline $\mathrm{C}_{20: 5 \mathrm{n}-3}$ Eicosapentaenoic & 4.32 & 1.63 & 2.35 & 2.91 & 3.22 \\
\hline $\mathrm{C}_{22: 5 \mathrm{n}-3}$ Docosapentaenoic & 0.86 & - & - & - & - \\
\hline $\mathrm{C}_{22: 6 \mathrm{n}-3}$ Docosahexaenoic & 11.77 & 2.20 & 3.41 & 3.83 & 4.60 \\
\hline \multicolumn{6}{|l|}{ Fatty acid characteristic } \\
\hline$\sum \mathrm{SFA}^{3}$ & 37.21 & 25.77 & 28.47 & 29.63 & 30.92 \\
\hline$\sum \mathrm{UFA}^{4}$ & 59.93 & 69.75 & 71.56 & 74.63 & 75.09 \\
\hline$\sum$ MUFA $^{5}$ & 23.09 & 31.51 & 28.78 & 28.43 & 26.41 \\
\hline$\sum \mathrm{PUFA}^{6}$ & 36.84 & 38.24 & 42.78 & 46.20 & 48.68 \\
\hline$\sum \mathrm{n}-6$ & 6.54 & 30.43 & 32.09 & 34.05 & 35.10 \\
\hline$\sum \mathrm{n}-3$ & 20.86 & 5.87 & 7.42 & 8.52 & 9.80 \\
\hline$\sum n-6 / \sum n-3$ & 0.31 & 5.18 & 4.32 & 3.99 & 3.58 \\
\hline
\end{tabular}

${ }^{1}$ Means of two replications. ${ }^{2} \mathrm{FO}$ (anchovy). ${ }^{3} \mathrm{SFA}=$ Saturated fatty acids. ${ }^{4} \mathrm{UFA}=$ Unsaturated fatty acids.

${ }^{5} \mathrm{MUFA}=$ Monounsaturated fatty acids. ${ }^{6} \mathrm{PUFA}=$ Polyunsaturated fatty acids. 
(AOAC, 1990) using a $50 \times 0.25 \mathrm{~mm}$ (inside diameter) WCOT fused silica CP-Sil 88 capillary column installed on a Hewlett Packard 5890 gas liquid chromatography with flame ionization detector.

The composition and chemical analyses of the diets are presented in Table 2. The nutrient content of diets was determined by proximate analysis (Naumann and Bassler, 1993). The experimental diets were analyzed for starch, sugar, total calcium $(\mathrm{Ca})$ and phosphorus $(\mathrm{P})$ according to the VDLUFA method (Naumann and Bassler, 1993). The metabolizable energy content of the diets was calculated based on the chemical composition of the diet (Anonymous, 1991).

The experiment used a completely randomized design, and each experimental unit was a replicate consisting of eight groups of adjacently caged layer hens fed as one group. The data was analyzed on two-factorial ANOVA using the general linear models procedure found in SAS software (SAS, 1991). The main effects of SFAT, period, and SFAT by period interaction were tested. Duncan's multiple range test was carried out to detect differences among treatments. All differences were considered significant at $\mathrm{p}<0.05$.

\section{RESULTS AND DISCUSSION}

The SFAT supplementation of the hens' diet resulted in an improvement in most of the studied traits, including egg weight. However, the final body weight and gain were lower for hens fed added-SFAT diets, by $1.2 \%$ and $1.8 \%$

Table 2. Ingredients and chemical composition of the layer diets (as fed)

\begin{tabular}{|c|c|c|c|c|}
\hline \multirow{2}{*}{ Ingredients } & \multicolumn{4}{|c|}{ SFAT $(\%)$} \\
\hline & 0.0 & 0.6 & 1.2 & 1.8 \\
\hline Corn & 55.63 & 53.42 & 51.37 & 49.25 \\
\hline Wheat & 10.00 & 10.00 & 10.00 & 10.00 \\
\hline Soybean meal ( $46 \% \mathrm{CP})$ & 17.00 & 17.00 & 17.00 & 17.00 \\
\hline Sunflower meal (31\% CP) & 1.15 & 3.35 & 5.52 & 7.70 \\
\hline Meat and bone meal ( $32 \% \mathrm{CP})$ & 4.96 & 4.98 & 5.00 & 5.00 \\
\hline Fish meal (64\% CP) & 3.26 & 2.60 & 1.79 & 1.06 \\
\hline SFAT & 0.00 & 0.60 & 1.20 & 1.80 \\
\hline Limestone & 7.20 & 7.25 & 7.31 & 7.36 \\
\hline Dicalcium phosphate & 0.10 & 0.10 & 0.11 & 0.13 \\
\hline Sodium chloride & 0.25 & 0.25 & 0.25 & 0.25 \\
\hline Vitamin premix $^{1}$ & 0.25 & 0.25 & 0.25 & 0.25 \\
\hline Mineral premix ${ }^{2}$ & 0.10 & 0.10 & 0.10 & 0.10 \\
\hline DL-methionine (98\%) & 0.10 & 0.10 & 0.10 & 0.10 \\
\hline \multicolumn{5}{|l|}{ Chemical composition $(\%)$} \\
\hline Dry matter & 89.25 & 89.50 & 90.13 & 90.03 \\
\hline Crude protein & 17.60 & 17.46 & 17.80 & 17.39 \\
\hline Ether extract & 3.38 & 3.80 & 4.16 & 4.53 \\
\hline Crude fiber & 2.99 & 3.42 & 3.85 & 4.38 \\
\hline Crude ash & 12.04 & 11.90 & 11.67 & 12.54 \\
\hline Starch & 39.45 & 39.15 & 38.74 & 38.47 \\
\hline Glucose & 4.25 & 4.40 & 3.91 & 3.68 \\
\hline Calcium & 3.73 & 3.68 & 3.57 & 3.52 \\
\hline Total phosphorus & 0.67 & 0.65 & 0.63 & 0.64 \\
\hline Metabolizable en. (kcal/kg) & 2,829 & 2,853 & 2,860 & 2,855 \\
\hline \multicolumn{5}{|l|}{ Calculated composition (\%) } \\
\hline Linoleic acid & 1.01 & 1.20 & 1.39 & 1.56 \\
\hline Lysine & 0.92 & 0.91 & 0.90 & 0.90 \\
\hline Methionine+cystine & 0.69 & 0.69 & 0.69 & 0.69 \\
\hline Threonine & 0.65 & 0.65 & 0.64 & 0.64 \\
\hline
\end{tabular}

${ }^{1}$ Supplied per kilogram of diet: vitamin $\mathrm{A}, 12,000 \mathrm{IU}$; vitamin $\mathrm{D}_{3}, 2,400 \mathrm{IU}$; vitamin E, $30 \mathrm{mg}$; vitamin $\mathrm{K}_{3}, 2.5 \mathrm{mg}$; vitamin $\mathrm{B}_{1}, 3 \mathrm{mg}$; vitamin $\mathrm{B}_{2}, 7 \mathrm{mg}$; vitamin $\mathrm{B}_{6}, 4 \mathrm{mg}$; vitamin $\mathrm{B}_{12}, 15 \mu \mathrm{g}$; nicotin amide, $40 \mathrm{mg}$; pantothenic acid, $8 \mathrm{mg}$; folic acid, $1 \mathrm{mg}$; biotin, $0.045 \mathrm{mg}$; vitamin $\mathrm{C}$, $50 \mathrm{mg}$; choline chloride $125 \mathrm{mg}$; ethoxyquin, $50 \mathrm{mg}$.

${ }^{2}$ Supplied per kilogram of diet: manganese, $80 \mathrm{mg}$; iron, $40 \mathrm{mg}$; zinc, $60 \mathrm{mg}$; copper, $5 \mathrm{mg}$; iodine, $0.4 \mathrm{mg}$; cobalt, $0.1 \mathrm{mg}$; selenium, $0.15 \mathrm{mg}$. 
Table 3. Body weight, body weight gain and mortality of laying hens

\begin{tabular}{|c|c|c|c|c|}
\hline \multirow{2}{*}{ SFAT $(\%)$} & \multicolumn{2}{|c|}{ Body weight $(\mathrm{g})$} & \multirow{2}{*}{$\begin{array}{c}\text { Body weight gain }(\mathrm{g}) \\
22 \text { to } 75 \mathrm{wk}\end{array}$} & \multirow{2}{*}{$\begin{array}{c}\text { Mortality (\%) } \\
22 \text { to } 75 \mathrm{wk}\end{array}$} \\
\hline & $22 \mathrm{wk}$ & $75 \mathrm{wk}$ & & \\
\hline$\% 0.0$ & 1,317 & $1,682^{\mathrm{a}}$ & $365^{\mathrm{a}}$ & 9.73 \\
\hline$\% 0.6$ & 1,314 & $1,673^{\mathrm{a}}$ & $359^{\mathrm{a}}$ & 7.64 \\
\hline$\% 1.2$ & 1,315 & $1,614^{\mathrm{b}}$ & $299^{\mathrm{b}}$ & 10.42 \\
\hline$\% 1.8$ & 1,317 & $1,641^{\mathrm{b}}$ & $324^{\mathrm{b}}$ & 8.34 \\
\hline Pooled SEM & 9.40 & 15.06 & 16.81 & 0.234 \\
\hline Probability & 0.995 & 0.006 & 0.048 & 0.368 \\
\hline
\end{tabular}

${ }^{\mathrm{a}-\mathrm{b}}$ Means with different superscripts letter within a column are significantly different $(\mathrm{p}<0.05)$.

respectively (Table 3 ). These results suggest that the hens given SFAT at corresponding levels maintained better productive performance despite their inferior body weight, as compared with those provided with $0 \%$ or $0.6 \%$ SFAT. Similar results were observed when laying hens were fed a diet supplemented by menhaden oil. Gonzales-Esquerra and Leeson (2000) reported that $2 \%$ and $5 \%$ dietary menhaden oil supplementation from 19 to 55 wks of age caused a

reduction in body weight gain by $34 \mathrm{~g}$ and $68 \mathrm{~g}$, respectively, without compromising the productive performance of layer hens. The mortality did not differ among the dietary treatments $(\mathrm{p}>0.05)$.

All of the performance traits studied was affected by experimental periods and dietary SFAT, except feed intake (Table 4). SFAT by period interactions were found significant for all of the indices tested, with the exception of

Table 4. Effects of SFAT on productive performance of layer hens

\begin{tabular}{|c|c|c|c|c|c|c|c|}
\hline Period & $\begin{array}{l}\text { SFAT } \\
(\%)\end{array}$ & $\begin{array}{c}\text { Egg production } \\
(\%)\end{array}$ & $\begin{array}{l}\text { Egg weigth } \\
\text { (g) }\end{array}$ & $\begin{array}{l}\text { Egg mass } \\
(\mathrm{g})\end{array}$ & $\begin{array}{l}\text { Feed intake } \\
(\mathrm{g} / \mathrm{d})\end{array}$ & $\begin{array}{l}\text { Feed conversion } \\
(\mathrm{kg} / \mathrm{kg})\end{array}$ & $\begin{array}{c}\text { Cracked-broken } \\
\text { egg }(\%)\end{array}$ \\
\hline \multirow[t]{4}{*}{ I } & 0 & $87.05^{\mathrm{b}}$ & $56.34^{\mathrm{f}}$ & $49.04^{c}$ & $98.11^{\mathrm{c}}$ & $2.00^{\mathrm{b}}$ & $0.66^{\mathrm{d}}$ \\
\hline & 0.6 & $86.91^{\mathrm{b}}$ & $56.68^{\mathrm{f}}$ & $49.26^{\mathrm{c}}$ & $97.90^{c}$ & $1.99^{\mathrm{b}}$ & $0.45^{\mathrm{d}}$ \\
\hline & 1.2 & $88.13^{\mathrm{ab}}$ & $56.56^{\mathrm{f}}$ & $49.84^{\mathrm{c}}$ & $97.81^{\mathrm{c}}$ & $1.95^{\mathrm{b}}$ & $0.90^{\mathrm{d}}$ \\
\hline & 1.8 & $89.16^{\mathrm{a}}$ & $56.35^{\mathrm{f}}$ & $50.24^{\mathrm{c}}$ & $97.46^{\mathrm{c}}$ & $1.95^{\mathrm{b}}$ & $0.83^{\mathrm{d}}$ \\
\hline \multirow[t]{4}{*}{ II } & 0 & $85.34^{\mathrm{c}}$ & $63.75^{\mathrm{e}}$ & $54.40^{\mathrm{b}}$ & $114.46^{\mathrm{a}}$ & $2.11^{\mathrm{a}}$ & $1.75^{\mathrm{c}}$ \\
\hline & 0.6 & $84.82^{c}$ & $63.55^{\mathrm{e}}$ & $53.90^{\mathrm{b}}$ & $114.48^{\mathrm{a}}$ & $2.12^{\mathrm{a}}$ & $0.87^{\mathrm{d}}$ \\
\hline & 1.2 & $87.39^{\mathrm{b}}$ & $64.33^{\mathrm{d}}$ & $56.21^{\mathrm{a}}$ & $115.58^{\mathrm{a}}$ & $2.05^{\mathrm{b}}$ & $1.36^{\mathrm{c}}$ \\
\hline & 1.8 & $84.55^{\mathrm{c}}$ & $64.19^{d}$ & $54.27^{\mathrm{b}}$ & $114.03^{\mathrm{a}}$ & $2.10^{\mathrm{a}}$ & $1.51^{\mathrm{c}}$ \\
\hline \multirow[t]{4}{*}{ III } & 0 & $74.30^{\mathrm{f}}$ & $65.96^{\mathrm{c}}$ & $49.00^{\mathrm{c}}$ & $100.54^{\mathrm{b}}$ & $2.04^{\mathrm{b}}$ & $4.98^{\mathrm{a}}$ \\
\hline & 0.6 & $78.80^{\mathrm{e}}$ & $65.76^{\mathrm{c}}$ & $51.81^{\mathrm{b}}$ & $99.59^{\mathrm{b}}$ & $1.91^{\mathrm{c}}$ & $3.28^{\mathrm{b}}$ \\
\hline & 1.2 & $80.94^{\mathrm{d}}$ & $66.28^{\mathrm{b}}$ & $53.64^{\mathrm{b}}$ & $101.53^{\mathrm{b}}$ & $1.88^{\mathrm{c}}$ & $3.66^{\mathrm{b}}$ \\
\hline & 1.8 & $84.43^{c}$ & $67.25^{\mathrm{a}}$ & $56.77^{\mathrm{a}}$ & $104.75^{\mathrm{a}}$ & $1.84^{\mathrm{d}}$ & $3.18^{\mathrm{b}}$ \\
\hline \multicolumn{2}{|c|}{ Pooled SEM } & 0.49 & 0.17 & 1.29 & 1.12 & 0.03 & 0.19 \\
\hline \multicolumn{8}{|c|}{ SFAT (\%) } \\
\hline \multicolumn{2}{|l|}{0} & $82.23^{\mathrm{c}}$ & $62.02^{\mathrm{b}}$ & $50.99^{\mathrm{b}}$ & 104.37 & $2.05^{\mathrm{a}}$ & $2.46^{\mathrm{a}}$ \\
\hline \multicolumn{2}{|l|}{0.6} & $83.51^{\mathrm{b}}$ & $62.00^{\mathrm{b}}$ & $51.77^{\mathrm{b}}$ & 103.99 & $2.01^{\mathrm{ab}}$ & $1.56^{\mathrm{b}}$ \\
\hline \multicolumn{2}{|l|}{1.2} & $85.49^{\mathrm{a}}$ & $62.39^{\mathrm{a}}$ & $53.33^{\mathrm{a}}$ & 104.98 & $1.96^{\mathrm{b}}$ & $1.97^{\mathrm{b}}$ \\
\hline \multicolumn{2}{|l|}{1.8} & $86.04^{\mathrm{a}}$ & $62.60^{\mathrm{a}}$ & $53.86^{\mathrm{a}}$ & 105.41 & $1.96^{\mathrm{b}}$ & $1.84^{\mathrm{b}}$ \\
\hline \multicolumn{2}{|c|}{ Pooled SEM } & 0.28 & 0.09 & 0.49 & 0.65 & 0.02 & 0.11 \\
\hline \multicolumn{8}{|l|}{ Period } \\
\hline \multicolumn{2}{|c|}{ I (22-39 wk) } & $87.81^{\mathrm{a}}$ & $56.48^{\mathrm{c}}$ & $49.59^{c}$ & $97.82^{\mathrm{c}}$ & $1.97^{\mathrm{b}}$ & $0.71^{\mathrm{c}}$ \\
\hline \multicolumn{2}{|c|}{ II (40-57 wk) } & $85.52^{\mathrm{b}}$ & $63.95^{\mathrm{b}}$ & $54.69^{\mathrm{a}}$ & $114.63^{\mathrm{a}}$ & $2.09^{\mathrm{a}}$ & $1.37^{\mathrm{b}}$ \\
\hline \multicolumn{2}{|c|}{ III (58-75 wk) } & $79.61^{\mathrm{c}}$ & $66.31^{\mathrm{a}}$ & $52.80^{\mathrm{b}}$ & $101.60^{\mathrm{b}}$ & $1.91^{\mathrm{b}}$ & $3.77^{\mathrm{a}}$ \\
\hline \multicolumn{2}{|c|}{ Pooled SEM } & 0.39 & 0.16 & 0.67 & 1.09 & 0.03 & 0.13 \\
\hline \multicolumn{2}{|c|}{ Source of variation } & ----- & ------- & ------- Pr & ility --------- & --------- & --------- \\
\hline \multicolumn{2}{|c|}{ SFAT } & 0.0001 & 0.0001 & 0.0487 & 0.4188 & 0.0492 & 0.0001 \\
\hline \multicolumn{2}{|c|}{ Period } & 0.0001 & 0.0001 & 0.0263 & 0.0001 & 0.0318 & 0.0001 \\
\hline \multicolumn{2}{|c|}{ SFAT $\times$ Period } & 0.0001 & 0.0001 & 0.0315 & 0.1154 & 0.0392 & 0.0001 \\
\hline
\end{tabular}

\footnotetext{
${ }^{\mathrm{a}-\mathrm{f}}$ Means with different superscripts letter within a column are significantly different $(\mathrm{p}<0.05)$.
} 
feed intake. The graded levels of SFAT addition into the basal diet increased the egg production rate $(\mathrm{p}<0.01)$ in a dose-dependent manner in Period III. The egg production rate of the $1.2 \%$ SFAT group was significantly higher than other groups in period II, while a similar pattern was observed for the $1.8 \%$ SFAT group in period III. The mean egg production rate of hens fed $1.2 \%$ and $1.8 \%$ SFAT added diets were higher $(\mathrm{p}<0.01)$ than that of hens fed diets with $0.6 \%$ SFAT and no SFAT.

Considering the overall mean, hens given diets supplemented with $1.2 \%$ and $1.8 \%$ SFAT laid heavier eggs than those hens fed diets with $0 \%$ and $0.6 \%$ SFAT $(\mathrm{p}<0.01)$ (Table 4). Quantitatively small improvements in egg weight (ranging from $0.40 \mathrm{~g}$ to $0.60 \mathrm{~g}$ ) with respect to corresponding SFAT treatments were found statistically significant $(\mathrm{p}<0.01)$. Specifically, the mean egg weight for hens fed a diet supplemented with $1.2 \%$ and $1.8 \%$ SFAT was the highest. As the hen aged, the eggs became heavier $(\mathrm{p}<0.01)$. The increased amount of linoleic acid in the diet was often related to increased egg weight in most previous studies (Shutze and Jensen, 1963; Scragg et al., 1987; March and MacMillian, 1990; Zimmerman, 1997). The positive relationship between increased dietary supplemental fat and egg weight is also well documented (Whitehead et al., 1991, 1993; Grobas et al., 1999, 2001). The improved egg weight of hens fed SFAT as a result of increased dietary linoleic acid and fat content in this study are in agreement with corresponding reports. Both higher n-3 fatty acids (eicosapentaenoic acid, $\mathrm{C}_{20: 5 \mathrm{n}-3}$ and docosahexaenoic acid, $\mathrm{C}_{22: 6 n-3}$ ) which were provided by supplemental FO might have been confirmatory of the increased egg weight in SFAT treated groups. Likewise, Whitehead et al. (1993) and Whitehead (1995) indicated that increased dietary fatty acids provided by SFAT may increase egg weight by stimulating the synthesis of oviducal proteins. Grobas et al. (1999) indicated that increasing dietary SFAT improved egg weight by $1.2 \mathrm{~g}$ in a long term laying hen trial (22 to $65 \mathrm{wks}$ ).

Egg mass output of the $1.2 \%$ or $1.8 \%$ SFAT group was significantly higher than that of the $0.6 \%$ or $0 \%$ SFAT group for the entire experimental period (Table 4). Hens fed on diets supplemented with SFAT at $1.2 \%$ and $1.8 \%$ yielded more egg mass, by over $2 \mathrm{~g}$ on average, as compared to hens that were not administered SFAT. The assumption that fatty acids in poultry diets supplied by SFAT were more readily absorbed through intestines and were more efficiently directed to egg mass constituents (Bray, 1967; March and MacMillian, 1990; Nimpf and Schneider, 1991) support the present findings of our study. It appears that relatively more fatty acids available in SFAT added diets might have efficaciously been utilized to constitute heavier eggs, as compared to a no-SFAT and $0.6 \%$ SFAT treated programs.
The overall means indicated that SFAT improved laying hen performance characteristics when supplemented into the diet at fairly low levels $(1.2 \%$ or $1.8 \%)$. However, this was barely the case for $4 \%$ or more FO inclusion, in the experimental conditions of other studies (Hargis et al., 1991; Grobas et al., 1999; Gonzales-Esquerra and Leeson, 2000). The differences in productive performance between this and above-mentioned earlier experiments were accounted for differentiation in hen genotype used, particularly their specific responds to dietary fat level. The white hen strain used in the present study (Nick Chick) producing egg mass at about $53 \mathrm{~g}$ may have had needed relatively fewer SFAT to satisfy their dietary energy (fat) requirements when compared to white and brown hen genotypes (i.e., DeKalb Delta and Isa Brown, respectively) producing heavier egg mass ranging from $56 \mathrm{~g}$ to $60 \mathrm{~g}$.

The level of added SFAT in the diets in this trial did not influence mean daily feed intake $(p>0.05)$ (Table 4). However, the feed intake stimulant effect with $1.8 \%$ SFAT was significant only in Period III $(\mathrm{p}<0.01)$. The markedly higher egg production, egg weight and egg mass, improved feed efficiency and less cracked-broken eggs in hens fed on a diet supplemented with $1.8 \%$ SFAT through Period III, was related to the notable increase in feed consumption (Table 4). This implies that SFAT at that level promoted feed intake; hence, the extra nutrients were directed to heavier egg mass production during that later phase of production, which corresponded to hot climatic conditions. The marked decline in feed intake of hens during the latest laying cycle (Period III) compared with previous stage (Period II) is related to the high environmental temperatures prevailed for 6 to $8 \mathrm{wks}$ during the corresponding period.

The feed conversion ratio was affected by SFAT and the age of the hen $(\mathrm{p}<0.05)$ (Table 4$)$. The overall feed conversion ratio of $1.2 \%$ and $1.8 \%$ SFAT groups was equal (1.96) and significantly improved when compared with the $0 \%$ SFAT group $(2.05 \%)$ correlated the improvements in laying rate, egg weight and egg mass.

SFAT also decreased the cracked-broken egg ratio during Period III, and throughout the entire experimental period, as compared to that for hens fed the diet without SFAT (Table 4). Nahashon et al. (1994) demonstrated that the retention of nitrogen, calcium, and phosphorous in white leghorn hens was significantly increased as a consequence of dietary fat supplementation at 3\%, and concluded that as the amount of SFAT increased, the feed passage time was extended. Therefore, the extra minerals absorbed by the SFAT-fed hens supposedly contributed to their larger egg size and improved eggshell mineralization.

The liver weight was not affected by the dietary treatments $(p>0.05)$. However, all levels of dietary supplementation with SFAT increased both the absolute and percentage weight of abdominal fat $(\mathrm{p}<0.01)$ (Table 5). It is 
Table 5. Absolute and percentage weight of liver and abdominal fat of SFAT-fed hens

\begin{tabular}{lcccc}
\hline SFAT $(\%)$ & $\begin{array}{c}\text { Liver } \\
(\mathrm{g})\end{array}$ & $\begin{array}{c}\text { Liver } \\
(\%)\end{array}$ & $\begin{array}{c}\text { Abdominal } \\
\text { fat }(\mathrm{g})\end{array}$ & $\begin{array}{c}\text { Abdominal } \\
\text { fat }(\%)\end{array}$ \\
\hline$\% 0.0$ & 35.60 & 2.17 & $20.84^{\mathrm{d}}$ & $1.27^{\mathrm{d}}$ \\
$\% 0.6$ & 38.44 & 2.36 & $32.55^{\mathrm{c}}$ & $2.01^{\mathrm{c}}$ \\
$\% 1.2$ & 36.86 & 2.33 & $68.88^{\mathrm{a}}$ & $4.37^{\mathrm{a}}$ \\
$\% 1.8$ & 34.63 & 2.19 & $54.30^{\mathrm{b}}$ & $3.39^{\mathrm{b}}$ \\
Pooled SEM & 2.23 & 0.10 & 5.20 & 0.34 \\
Probability & 0.3935 & 0.2961 & 0.0001 & 0.0001 \\
\hline
\end{tabular}

a-d Means with different superscripts letter within a column are significantly different $(\mathrm{p}<0.05)$.

supposed that the hens' ability to efficiently utilize dietary fat might result extra abdominal fat deposition in hens fed on diets added with SFAT (Sell et al., 1979; Matéos and Sell, 1981a). The increased dietary fat was deposited in the adipose tissue of the abdomen. Indeed, hens that were fed SFAT at inclusion levels of $1.2 \%$ and $1.8 \%$ produced greater egg mass in spite of the similar amount of feed intake, as compared to hens fed without SFAT, and they also deposited significantly more abdominal fat than those hens that did not receive any SFAT. This can be explained by a mechanism asserted by some scholars (Matéos and Sell, 1981b; Golian and Maurice, 1992); i.e., high fat diets may slow down the rate of the passage of digesta through the gastrointestinal tract, thereby allowing more time for the absorption and utilization of nutrients, such as nitrogen and fat.

In conclusion, the results showed that SFAT markedly improved laying hen performance, despite the lower body weight and heavier abdominal fat pad. The SFAT also proved benefits in terms of decreasing the cracked-broken egg ratio. Incorporation SFAT into a corn-soybean-based practical diet at the level of $1.2 \%$ or $1.8 \%$, which provides 3.8 to $4.5 \%$ in dietary crude fat with 1.2 to $1.5 \%$ in linoleic acid, respectively, could maximize the overall productive performance in a commercial white layer hen strain.

\section{REFERENCES}

Anonymous. 1991. Animal feeds-Determination of metabolizable energy (chemical method). Turkish Standards Institute (TSE), Publ. No. 960, 1-3.

AOAC. 1990. Official methods of analysis (15th Ed). Association of Official Analytical Chemists, Inc., Washington DC, USA.

Baucells, M. D., N. Crespo, A. C. Barroeta, S. Lopez-Ferrer and M. A. Grashorn. 2000. Incorporation of different polyunsaturated fatty acids into eggs. Poult. Sci. 79:51-59.

Bray, D. J. 1967. The effect of restricted calorie intake upon the egg weight response to dietary corn oil. Poult. Sci. 46:476-484.

da Silva Filardi, R., O. M. Junqueria, A. C. de Laurentiz, E. M. Casartelli, E. Aperecidia Rodrigues and L. Francelino Araú. 2005. Influence of different fat sources on the performance, egg quality, and lipid profile of egg yolks of commercial layers in the second laying cycle. J. Appl. Poult. Res. 6:258-264.

Golian, A. and D. V. Maurice. 1992. Dietary poultry fat and gastrointestinal transit time of feed and fat utilization in broiler chickens. Poult. Sci. 71:1357-1363.

Gonzales-Esquerra, R. and S. Leeson. 2000. Effect of feeding hens regular or deodorized menhaden oil on production parameters, yolk fatty acid profile, and sensory quality of eggs. Poult. Sci. 79:1597-1602.

Grobas, S., J. Mendez, C. De Blas and G. G. Matéos. 1999. Laying hen productivity as affected by energy, supplemental fat, and linoleic acid concentration of the diet. Poult. Sci. 78:15421551.

Grobas, S., J. Mendez, R. Lazara, C. De Blas and G. G. Mateos. 2001. Influence of source and percentage of fat added to diet on performance and fatty acid composition of egg yolks of two strains of laying hens. Poult. Sci. 80:1171-1179.

Hargis, P. S., M. E. Van Elswyk and B. M. Hargis. 1991. Dietary modification of yolk lipid with Menhaden oil. Poult. Sci. 70:874-883.

Keshavarz, K. 1995. Further investigations on the effect of dietary manipulations of nutrients on early egg weight. Poult. Sci. 74: 62-74.

Leskanich, C. O. and R. C. Noble. 1997. Manipulation of the $n-3$ polyunsaturated fatty acid composition of avian eggs and meat. World's Poult. Sci. 53:155-183.

March, B. E. and C. MacMillan. 1990. Linoleic acid is a mediator off egg size. Poult. Sci. 69:634-639.

Matéos, G. G. and J. L. Sell. 1981a. Nature of the extra metabolic effect of supplemental fat used in semi purified diets for laying hens. Poult. Sci. 60:1925-1931.

Matéos, G. G. and J. L. Sell. 1981b. Influence of fat and carbohydrate source on rate of passage of semi purified diets for laying hens. Poult. Sci. 60:2114-2119.

Matéos, G. G., J. L. Sell and J. A. Eastwood. 1982. Rate of passage (transit time) as influenced by level of supplemental fat. Poult. Sci. 61:94-100.

Nahashon, S. N., H. S. Nakaue and L.W. Mirosh. 1994. Production variables and nutrient retention in single comb white leghorn laying pullets fed diets supplemented with direct-fed microbials. Poult. Sci. 73:1669-1711.

Naumann, C. and R. Bassler. 1993. Die chemische Untersuchung von Futtermitteln. Methodenbuch, Band III. 3. Erg., VDLUFAVerlag, Darmstadt.

Nimpf, J. and W. J. Schneider. 1991. Receptor-mediated lipoprotein transport in laying hens. J. Nutr. 121:1471-1474.

SAS Institute. 1991. SAS ${ }^{\circledR}$ User's Guide: Statistics. Version 6.03 edition .SAS Institute Inc., Cary, NC.

Scragg, R. H., N. B. Logan and N. Geddes. 1987. Response of egg weight to the inclusion of various fats in layer diets. Br. Poult. Sci. 28:15-21.

Sell, J. L., F. Horani and R. L. Canson. 1979. The 'extra caloric' effect of fat in laying hen rations. Feedstuffs 48:27-28.

Sell, J. L., C. R. Angel and F. Escribano. 1987. Influence of supplemental fat on weights of eggs and yolks during early egg production. Poult. Sci. 66:1807-1812.

Shutze, J. V. and L. S. Jensen. 1963. Influence of linoleic acid on egg weight. Poult. Sci. 42:921-924. 
Whitehead, C. C. 1981. The response of egg weight to the inclusion of different amounts of vegetable oil and linoleic acid in the diet of laying hens. Br. Poult. Sci. 22:525-532.

Whitehead, C. C., A. S. Bowman and H. D. Griffin. 1991. The effects of dietary fat and bird age on the weights of eggs and egg components in the laying hen. Br. Poult. Sci. 32:565-574.
Whitehead, C. C., A. S. Bowman and H. D. Griffin. 1993. Regulation of plasma oestrogen by dietary fats in laying hen: Relationship with egg weight. Br. Poult. Sci. 34:999-1010.

Whitehead, C. C. 1995. Plasma oestrogen and the regulation egg weight in laying hens by dietary fats. Anim. Feed Sci. Technol. 53:91-98.

Zimmerman, R. A. 1997. Management of egg size through precise nutrient delivery. J. Appl. Poult. Res. 6:478-482. 